\title{
ANALISIS MISKONSEPSI SISWA KELAS VIII PADA SUB MATERI PENYELESAIAN SPLDV DAN PENERAPAN SPLDV MENGGUNAKAN THREE TIER- TEST
}

\author{
Edwaldus Dedeng ${ }^{1}$, Trija Fayeldi ${ }^{2}$, Rosita Dwi Ferdiani ${ }^{3}$ \\ Program Studi Pendidikan Matematika Universitas Kanjuruhan Malang ${ }^{1,2,3}$ \\ edwaldus.dedeng@gmail.com ${ }^{1}$,trija_fayeldi@unikama.ac.id ${ }^{2}$,Rositadf@gmail.com ${ }^{3}$
}

\begin{abstract}
Abstrak. Pemahaman konsep merupakan hal yang sangat diperlukan dalam pembelajaran matematika, sehingga bisa memecahkan masalah dalam pembelajaran matematika sesuai dengan konsep yang dipahami. Sebaliknya, apabila tidak memahami konsep yang selanjutnya disebut miskonsepsi tidak bisa memecahkan masalah dalam pembelajaran matematika. Penelitian ini menggunakan metode deskriptif dengan pendekatan penelitian kualitatif. Teknik pengumpulan data adalah tes tertulis dan wawancara. Soal tes yang digunakan adalah soal tes berbentuk three tier test. Siswa kelas VIII SMP yang berjumlah 28 orang siswa dijadikan sebagai populasi, dan sebanyak 6 siswa dari 28 siswa dijadikan sebagai subjek penelitian. Hasil penelitian ini, rata-rata siswa mengalami miskonsepsi pada soal nomor 3 dan 4 yang menanyakan tentang himpunan penyelesaian dan soal cerita yang berkaitan dengan kehidupan sehari-hari. Siswa yang mengalami miskonsepsi dikarenakan belum mampu menentukan sebarang bilangan untuk mengeliminasi salah satu variabel serta belum mampu menerjemahkan soal cerita ke dalam bentuk matematika. Selain mengalami miskonsepsi siswa juga lucky guess (menjawab benar dengan menebak). Adapun subyek yang mengalami miskonsepsi pada soal nomor 3 berjumlah 4 siswa dan soal nomor 4 berjumlah 4 siswa. Berdasarkan hasil penelitian dengan menggunakan three tier test maka dapat disimpulkan bahwa sebagian besar siswa mengalami miskonsepsi pada salah satu soal bahkan lebih. Selain mengalami miskonsepsi siswa juga mengalami lucky guess serta mengalami konsepsi ilmiah.
\end{abstract}

Kata Kunci: Miskonsepsi, Three Tier Test, Sistem Persamaan Linear Dua Variabel

\section{PENDAHULUAN}

Matematika merupakan salah satu cabang ilmu pengetahuan yang memiliki pengaruh yang sangat signifikan baik dalam perkembangan teknologi maupun dalam penemuan ilmu ekonomi, serta cabang ilmu dipelajari disemua jenjang pendidikan. Menurut Russefendi (dalam Siagian, 2016) matematika yaitu ilmu yang menjelaskan pola atau keteraturan dan tingkatan. Adapun Siswono (dalam Siagian, 2016) juga mencatat kumpulan pengertian matematika yang dibuat oleh ahli-ahli pada tahun1940-an sampai dengan 1970-an. Beberapa pengertian matematika antara lain: (1) matematika yaitu ilmu tentang bilangan dan ruang, (2) matematika yaitu ilmu tentang besaran (kuantitas), (3) matematika sebagai ilmu tentang bilangan, ruang, besaran, dan keluasan, (4) matematika sebagai ilmu tentang hubungan (relasi), (5) matematika sebagai ilmu tentang bentuk yang abstrak, dan (6) matematika sebagai ilmu yang bersifat deduktif. Matematika memiliki ciri-ciri, seperti yang dikemukakan oleh Soedjadi (dalam Siagian, 2016:60), yaitu : (1) memiliki objek yang konseptual, (2) berpijak pada kesepakatan (3) berpola pikir deduktif, (4) memperhatikan semesta pembicaraan, (5) konsisten dalam sistemnya.

Berdasarkan ciri-ciri diatas tidak heran apabila matematika merupakan mata pelajaran yang harus ditempuh oleh setiap jenjang pendidikan baik dari sekolah dasar, sampai pada jenjang yang lebih tinggi yaitu perguruan tinggi. Hal yang sangat diperlukan dalam pembelajaran matematika adalah pemahaman konsep siswa terhadap matematika itu sendiri, sehingga bisa memecahkan masalah dalam pembelajaran matematika yang sesuai dengan 
konsep yang dipahami, sebaliknya apabila siswa tidak memahami konsep atau salah memahami konsep yang selanjutnya disebut miskonsepsi maka siswa tidak bisa memecahkan masalah dalam pembelajaran matematika, meskipun sesuai dengan konsep yang telah diajarkan. Hal ini sejalan dengan apa yang dikatakan oleh Marsitin (2018) yang menyatakan bahwa komunikasi matematis pemecahan masalah matematika, penaaran matematis, dan koneksi matematis merupakan kemampuan yang harus dicapai dalam pemebelajaran matematik. Adapun miskonsepsi yang dimaksud menurut Farida (2016) adalah penggunaan konsep yang salah, klasifikasi contoh yang salah, kekacauan konsep-konsep yang berbeda dan hubungan hierarkis konsep-konsep yang tidak benar yang dipahami seseorang dengan konsep yang benar. Menurut Tridiyanti \& Yuliani (2017) miskonsepsi adalah kesalahan konsep yang dilakukan oleh seseorang yang tetap menggunakan konsep awal yang dimilikinya pada hal orang tersebut telah dikenalkan dengan konsep yang benar.

Salah satu materi yang sering kali mengalami miskonsepsi oleh siswa pada pembelajaran matematika adalah sistem persamaan linear dua variabel (SPLDV) sehingga kemampuan pemahaman konsep serta pengaplikasian konsep sangat ditekankan pada materi SPLDV. Selain karena berpengaruh terhadap materi selanjutnya, hal ini juga disebakan karena SPLDV merupakan salah satu konsep dasar matematika, penerapannya pun banyak digunakan dalam kehidupan sehari-hari, tidak saja berkaitan dengan penilaian akademik oleh guru tetapi juga permasalahan dalam bentuk soal cerita dalam kehidupan sehari-hari yang merupakan pengaplikasian nyata ilmu matematika. Penjelasan ini mengisyaratkan pentingnya siswa memahami soal cerita pada materi SPLDV.

Hasil UNBK dari tahun 2017 sampai tahun 2019 berdasarkan data dari Kemendikbud (puspendik.kemdikbud.go.id) bahwa pada tahun 2017 rata-rata nilai UNBK matematika 50,34; tahun 2018 rata-rata UNBK matematika 44,05; dan pada tahun 2019 rata-rata nilai UNBK matematika 46,56. Data diatas memberikan gambaran bahwa masih banyak siswa yang mengalami miskonsepsi matematika, sehingga tujuan pembelajaran matematika masih belum tercapai secara maksimal, dimana tujuan pembelajaran matematika yaitu memahami konsep matematika, menjelaskan hubungan antara konsep dan menerapkan konsep secara cermat, efektif dan tepat dalam pemecahan masalah seperti yang dikemukakan oleh Depdiknas (Permendiknas No.22 tahun 2003). Miskonsepsi yang dialami siswa sangat berpengaruh terhadap pemahaman konsep siswa untuk materi selanjutnya, karena pada dasarnya matematika merupakan mata pelajaran yang memiliki keterkaitan antara konsep yang satu dengan konsep yang lain.

Masalah yang dihadapi siswa SMP Negeri 2 Singosari sampai saat ini adalah masih banyak siswa yang mengalami miskonsepsi terhadap materi matematika terkhusus SPLDV. Hal ini diperkuat dengan hasil wawancara dengan guru matematika di SMP Negeri 2 Singosari bahwa masih banyak miskonsepsi yang dilakukan oleh siswa khususnya pada topik soal cerita materi sistem persamaan linear dua variabel. Salah satu miskonsepsi yang dialami siswa yaitu kurangnya keterampilan siswa dalam menerjemahkan kalimat matematika dan unsur mana yang dimisalkan dengan suatu variabel. Hal ini perlu ditangani dengan serius agar tidak berpengaruh pada siswa untuk materi selanjutnya.

Menurut Hermanto (dalam Murniasih, Ferdiani, Agustina,2018) pemahaman konsep yang dimiliki siswa akan mendorong siswa untuk memahami tentang apa yang mereka pelajari dan menjelaskan kembali dengan bahasanya sendiri. Faktor yang mengakibatkan rendahnya tingkat pemahaman siswa terhadap suatu materi yaitu siswa tidak memahami konsep atau juga kesalahan siswa dalam memahami konsep atau disebut miskonsepsi. Salah satu cara yang dapat digunakan untuk menganalisis miskonsepsi siswa adalah dengan menggunakan tes diagnostik, yaitu dengan menggunakan Three Tier-Test. Penelitian terdahulu tentang miskonsepsi siswa ini pernah diteliti oleh (Indana, 2013) yang berjudul Analisis Miskonsepsi Siswa Dengan Certainty Of Response Index Dalam Menyelesaiakan Soal Cerita Materi Sistem Persamaan Linear Dua Variabel Kelas VIII MTS Hasyim Asyari Hasil penelitian tersebut adalah dari kelima subjek pada soal no 1, 2 dan 5 semuanya menguasai konsep dengan baik. Selain itu, terdapat subjek yang mengalami miskonsepsi yaitu $S_{1}$ pada soal no 3. Berdasarkan penelusuran yang lebih terperinci yaitu hasil wawancara diperoleh bahwa subjek $\mathrm{S}_{4}$ mengalami lucky guess (menjawab 
benar dengan menebak) pada soal no 2. Namun untuk soal no 3 dan 4 dari kelima subjek yaitu $\mathrm{S}_{1}, \mathrm{~S}_{2}, \mathrm{~S}_{3}, \mathrm{~S}_{4}, \mathrm{~S}_{5}$, mengalami tidak tahu konsep dalam menyelesaikan soal tersebut.

Savitri, dkk (2016) dengan berjudul Analisis Miskonsepsi Siswa Pada Materi Pecahan Dalam Bentuk Aljabar Ditinjau Dari Gaya Kognitif Siswa Kelas VIII Di SMP Negeri 2 Adimulyo Kabupaten Kebumen Tahun Ajaran 2013/2014. Hasil penelitian tersebut didapatkan hasil bahwa bahwa miskonsepsi dapat terjadi pada setiap siswa, baik siswa yang memiliki gaya kognitif Field Dependence (FD) yang memiliki cara berpikir rendah dalam menyelesaikan permasalahan matematika, maupun siswa dengan gaya kognitif Field Independence (FI) yang memiliki cara berpikir tinggi dalam pemecahan masalah matematika. Siswa kelas VIIIA SMP Negeri 2 Adimulyo sebagian besar mengalamimiskonsepsi pada materi pecahan dalam bentuk aljabar. Kebanyakan para siswa hanya memahami perhitungannya tanpa memahami konsepnya. Sehingga ketika dihadapkan pada persoalan yang baru,mereka mengalami kebingungan yang berujung terjadinya miskonsepsi.

Dari kedua penelitian terdahulu di atas, hal yang membedakan dengan penelitian yang dilakukan peneliti antara lain : (1) penelitian yang dilakukan oleh Indana (2016) terletak pada diagnostik yang digunakan yaitu certainty of response index, (2) Savitri.,dkk (2016) terletak pada variabel yaitu ditinjau dari dari gaya kognitif siswa. Pada penelitian ini, peneliti melakukan penelitian dengan menggunakan Three Tier Test.

\section{METODE PENELITIAN}

Jenis pendekatan yang digunakan dalam penelitian ini adalah pendekatan kualitatif. Pendekatan kualitatif digunakan untuk mengolah kata-kata tertulis atau lisan. Adapun, jenis penelitian yang digunakan dalam penelitian ini adalah penelitian deskriptif yang $b$ ertujuan untuk menganalisis miskonsepsi apa saja yang dialami siswa di SMP Negeri 2 Singosari. Populasi dalam penelitian ini sebanyak 28 siswa kelas VIII C semester ganjil tahun ajaran 2019/2020 SMP Negeri 2 Singosari. Objek penelitian ini sebayak 6 siswa berdasarkan miskonsepsi yang paling dominan dilakukan siswa. Adapun instrumen yang dipakai adalah (1) soal tes yaitu soal berupa three tier test yang terdiri dari tiga tingkatan. Tingkatan pertama adalah menanyakan pengetahuan siswa tentang konsep dari pilihan ganda. Tingkatan kedua adalah penalaran siswa dari proses menjawab pada tingkatan pertama. Tingkatan ketiga adalah pertanyaan mengenai keyakinan siswa tentang jawaban tingkatan pertama dan kedua. (2) Pedoman wawancara yang berisi pertanyaan-pertanyaan yang akan digunakan untuk mengetahui miskonsepsi peserta didik secara lebih terbuka. (3) Lembar validasi yang berisi aspek petunjuk pengerjaan soal, aspek isi tes dan aspek bahasa. Proses analisis data yang direncanakan dalam penelitian ini adalah melakukan analisis data tertulis. Analisis data tertulis dilakukan berdasarkan hasil tes. Selain data tertulis dilakukan pula analisis data berdasarkan hasil wawancara. Analsis data tersebut meliputi :

\section{Reduksi data}

Proses reduksi data pada hasil tes yaitu mengoreksi setiap jawaban pada hasil tes tertulis yang telah dilakukan siswa. Miskonsepsi yang dominan dilakukan siswa akan dijadikan sebagai salah satu kategori jawaban siswa yang dipilih sebagai sampel penelitian. Proses mendengarkan rekaman hasil wawancara peneliti dengan sampel penelitian disebut proses reduksi data hasil wawancara. Selanjutnya mengubah rekaman tersebut dalam bentuk kutipan wawancara yang disusun dalam bentuk bahasa yang baik sehingga mudah dipahami.

Reduksi data bertujuan untuk memilah dan memilih serta menyederhanakan data agar tidak terjadi penumpukan data yang sama. Setelah direduksi data akan menyajikan paparan data yang lebih jelas tentang hasil pengamatan yang telah dilakukan peneliti.

\section{Penyajian Data}

Penyajian data dapat diartikan sebagai usaha untuk menyusun atau menata sekumpulan informasi yang telah diperoleh di lapangan dengan menyajikan data tersebut secara jelas dan sistematis. Dalam penelitian ini hasil analisis data disajikan dalam bentuk tabel keputusan Three tier-test, yang dibagi dalam tiga tingkatan serta keputusan Three Tier-test. Dari tabel tersebut penyajian data dilanjutkan dengan uraian singkat dalam bentuk teks tertulis yang bersifat 
naratif. Penyajian data ini bertujuan untuk memunculkan dan menunjukan kumpulan data atau informasi yang terorganisir dan terkategori yang memungkinkan suatu penarikan kesimpulan atau tindakan.

\section{Penarikan kesimpulan}

Dari uraian singkat yang telah disajikan, akan didapatkan sebuah kesimpulan. Penarikan kesimpulan dalam penelitian ini yaitu dengan cara mengkroscek jawaban siswa pada saat menyelesaiakan soal dengan jawaban siswa saat diwawancara. Dari sini akan ditemukan miskonsepsi dari masing-masing siswa setelah menyelesaikan soal SPLDV.

Adapun tabel keputusan three tier test yang dimaksud adalah sebagai berikut

Tabel 1 Keputusan Three Tier Test

\begin{tabular}{cccc}
\hline Tingkatan 1 & Tingkatan 2 & Tingkatan 3 & Keputusan \\
\hline Benar & Benar & Yakin & Konsepsi Ilmiah \\
\hline Benar & Salah & Yakin & Miskonsepsi \\
\hline Salah & Salah & Yakin & Miskonsepsi \\
\hline Salah & Benar & Yakin & Miskonsepsi \\
\hline Benar & Salah & Tidak Yakin & Menebak \\
\hline Salah & Benar & Tidak Yakin & Menebak \\
\hline Benar & Benar & Tidak Yakin & Lucky Guess \\
\hline Salah & Salah & Tidak Yakin & Lack Of Knowlegde \\
\hline
\end{tabular}

Sumber: Maulini.,dkk(2016)

Untuk menjaga keabsahan data hasil tes dan wawancara yang telah dianalisis, selanjutnya peneliti memeriksa keabsahan data yang telah diperoleh menggunakan triangulasi. Pada penelitian ini, uji keabsahan data menggunakan triangulasi metode. Triangulasi yaitu membandingkan dan mengecek balik tingkat kepercayaan suatu informasi yang diperoleh dari hasil tes peneliti dengan hasil wawancara. Apabila ditemukan perbedaan data, maka perlu diadakan diskusi untuk memastikan kebenaran data

\section{HASIL DAN PEMBAHASAN}

Peneliti menganalisis dan mengumpulkan data dari subjek penelitian berupa hasil tes miskonsepsi yang disajikan dalam tabel keputusan three tier test .

\section{Subjek 1}

Tabel 2 Identifikasi Miskonsepsi Subjek 1

\begin{tabular}{ccccc}
\hline Soal & Tingkatan 1 & Tingkatan 2 & Tingkatan 3 & Kesimpulan \\
\hline 1 & Salah & Benar & Yakin & Miskonsepsi \\
\hline 2 & Benar & Benar & Yakin & Konsepsi Ilmiah \\
\hline 3 & Salah & Salah & Yakin & Mikonsepsi \\
\hline 4 & Benar & Salah & Tidak Yakin & Menebak \\
\hline
\end{tabular}

Berdasarkan identifikasi subjek 1, didapat kesimpulan bahwa subjek mengalami miskonsepsi pada soal 1 dan 3, dan menjawab dengan menebak pada soal nomor 4. Berdasarkan identifikasi subjek tersebut, pada soal nomor 1 subjek 1 belum memahami pengertian koefisien. Pemahaman subjek 1 untuk koefisien tertuju pada suku pada persamaan. Adapun pada soal nomor 3, subjek 1 mengalami miskonsepsi pada operasi pembagian bilangan positif dan negatif yang berada pada ruas yang berbeda. Pada saat wawancara, subjek 1 mengatakan bahwa bilangan negatif yang menjadi pembagi mengalami perubahan tanda yaitu menjadi positif. Subjek 1 menjawab dengan menebak pada soal nomor 4 dikarenakan belum memahami penyelesaian model matematika. Adapaun pada soal nomor 2, subjek 1 mengalami konsepsi ilmiah atau paham konsep. 


\section{Subjek 2}

Tabel 3 Identifikasi Miskonsepsi Subjek 2

\begin{tabular}{ccccc}
\hline Soal & Tingkatan 1 & Tingkatan 2 & Tingkatan 3 & Kesimpulan \\
\hline 1 & Benar & Benar & Yakin & Konsepsi Ilmiah \\
\hline 2 & Salah & Salah & Yakin & Miskonsepsi \\
\hline 3 & Benar & Salah & Yakin & Mikonsepsi \\
\hline 4 & Benar & Benar & Tidak Yakin & Lucky Guess \\
\hline
\end{tabular}

Berdasarkan identifikasi subjek 2, didapat kesimpulan bahwa subjek mengalami miskonsepsi pada soal nomor 2 dan 3, dan mengalami lucky guess pada soal nomor 4. Berdasarkan identifikasi subjek tersebut, pada soal nomor 2, subjek 2 menganggap beda variabel yang sama yang dipisahkan oleh tanda sama dengan (=). Adapun pada soal nomor 3, subjek 2 mengalami miskonsepsi pada operasi pembagian bilangan positif dan negatif yang berada pada ruas yang berbeda. Pada saat wawancara, subjek 2 mengatakan bahwa bilangan negatif yang menjadi pembagi mengalami perubahan tanda yaitu menjadi positif. Subjek 2 mengalami lucky guess pada soal nomor 4 dikarenakan belum mampu mengubah soal cerita ke dalam bentuk matematika. Adapun pada soal nomor 1, subjek 2 mengalami konsepsi ilmiah atau paham konsep.

\section{Subjek 3}

Tabel 4 Identifikasi Miskonsepsi Subjek 3

\begin{tabular}{ccccc}
\hline Soal & Tingkatan 1 & Tingkatan 2 & Tingkatan 3 & Kesimpulan \\
\hline 1 & Benar & Salah & Tidak Yakin & Menebak \\
\hline 2 & Benar & Benar & Tidak Yakin & Lucky Guess \\
\hline 3 & Benar & Benar & Yakin & Konsepsi Ilmiah \\
\hline 4 & Salah & Salah & Yakin & Mikonsepsi \\
\hline
\end{tabular}

Berdasarkan identifikasi subjek 3, didapat kesimpulan bahwa subjek mengalami miskonsepsi pada soal nomor 4, mengalami lucky guess pada soal nomor 2, serta menjawab dengan menebak pada soal nomor 1. Berdasarkan identifikasi subjek tersebut, pada soal nomor 4, subjek 3 membuat konsep sendiri untuk menghindari hasil yang bernilai negatif. Adapun pada soal nomor 1, subjek 3 menjawab dengan menebak dikarenakan belum mampu membedakan pengertian koefisien dan variabel. Subjek 2 mengalami lucky guess pada soal nomor 2 karena menganggap tidak ada jawaban pada pilihan yang diberikan. Saat melakukan wawancara, subjek 3 memahami suatu persamaan dikatakan sebagai persamaan linear dua variabel apabila konstanta dipisahkan dengan suku dua (bentuk aljabar yang dihubungkan oleh satu operasi jumlah atau selisih). Adapun pada soal nomor 3 , subjek 3 mengalami konsepsi ilmiah atau paham konsep.

\section{Subjek 4}

Tabel 5 Identifikasi Miskonsepsi Subjek 4

\begin{tabular}{ccccc}
\hline Soal & Tingkatan 1 & Tingkatan 2 & Tingkatan 3 & Kesimpulan \\
\hline 1 & Benar & Benar & Yakin & Konsepsi Ilmiah \\
\hline 2 & Benar & Benar & Yakin & Konsepsi Ilmiah \\
\hline 3 & Salah & Salah & Yakin & Mikonsepsi \\
\hline 4 & Benar & Benar & Tidak Yakin & Lucky Guess \\
\hline
\end{tabular}

Berdasarkan identifikasi subjek 4, didapat kesimpulan bahwa subjek 4 mengalami miskonsepsi pada soal nomor 3 dan mengalami lucky guess pada soal nomor 4. Berdasarkan identifikasi subjek tersebut, pada soal nomor 3, subjek 4 mengalami miskonsepsi pada metode eliminasi. Saat dilakukan wawancara subjek 4 tidak mengeli-minasi 
salah satu variabel, akan tetapi mengalikan dengan sembarang bilangan untuk menjadikan bilangan di sebelah kanan tanda sama dengan (=) atau konstanta menjadi nol, selanjutnya jika di sebelah kanan sudah menjadi nol maka di sebelah kiri tanda sama dengan salah satunya pindah ke sebelah kanan. Subjek 4 mengalami lucky guess pada soal nomor 4 dikarenakan subjek 4 kurang memahami dalam mengubah soal cerita de dalam bentuk matematika. Adapun pada soal nomor 1 dan nomor 2, subjek 4 mengalami konsepsi ilmiah atau paham konsep.

\section{Subjek 5}

Tabel 6 Identifikasi Miskonsepsi Subjek 5

\begin{tabular}{ccccc}
\hline Soal & Tingkatan 1 & Tingkatan 2 & Tingkatan 3 & Kesimpulan \\
\hline 1 & Benar & Benar & Tidak Yakin & Lucky Guess \\
\hline 2 & Benar & Benar & Yakin & Konsepsi Ilmiah \\
\hline 3 & Salah & Salah & Yakin & Mikonsepsi \\
\hline 4 & Salah & Benar & Tidak Yakin & Menebak \\
\hline
\end{tabular}

Berdasarkan identifikasi subjek 5, didapat kesimpulan bahwa subjek 5 mengalami miskonsepsi pada soal nomor 3 dan mengalami lucky guess pada soal nomor 1 serta menjawab dengan menebak pada soal nomor 4. Berdasarkan identifikasi subjek tersebut, pada soal nomor 3, subjek 5 mengalami miskonsepsi pada operasi pembagian bilangan negatif dan bilangan positif. Saat dilakukan wawancara subjek 5 memahami bilangan yang bernilai negatif ketika dijadikan sebagai pembagi mengalami perubahan tanda yaitu menjadi positif. Subjek 5 mengalami lucky guess pada soal nomor 1 dikarenakan belum bisa membedakan pengertian koefisien dan variabel. Adapun pada soal nomor 4, subjek 5 menjawab dengan menebak dikarenakan subjek 5 belum memahami unsur mana yang dimisalkan dengan variabel pada penyelesaian soal cerita. Soal nomor 2 subjek 5 mengalami konsepsi ilmiah atau paham konsep.

\section{Subjek 6}

Tabel 7 Identifikasi Miskonsepsi Subjek 6

\begin{tabular}{ccccc}
\hline Soal & Tingkatan 1 & Tingkatan 2 & Tingkatan 3 & Kesimpulan \\
\hline 1 & Benar & Benar & Yakin & Konsepsi Ilmiah \\
\hline 2 & Benar & Benar & Yakin & Konsepsi Ilmiah \\
\hline 3 & Benar & Benar & Tidak Yakin & lucky guess \\
\hline 4 & Salah & Salah & Yakin & Mikonsepsi \\
\hline
\end{tabular}

Berdasarkan identifikasi subjek 6, didapat kesimpulan bahwa subjek 6 mengalami miskonsepsi pada soal nomor 4 dan mengalami lucky guess pada soal nomor 3. Berdasarkan identifikasi subjek tersebut, pada soal nomor 4 mengalami miskonsepsi yaitu belum memahami unsur mana yang dimisalkan dengan variabel. Subjek 6 mengalami lucky guess pada soal nomor 3, hal ini dikarenakan subjek 6 belum memahami penentuan bilangan untuk dikalikan pada persamaan untuk menghilangkan salah satu variabel. Adapan pada soal nomor 1 dan nomor 2, subjek 6 mengalami konsepsi ilmiah atau paham konsep.

\section{PENUTUP}

Berdasarkan hasil penelitian dan pembahasan maka dapat disimpulkan berdasarkan three tier test sebagai berikut : Miskonsepsi yaitu siswa yang memilih jawaban yang salah, memberikan alasan yang salah serta meyakini jawaban yang diberikan. Selain itu, siswa yang mengalami miskonsepsi merupakan siswa yang mampu memilih jawaban yang benar, namun tidak bisa memberikan alasan yang benar serta meyakini jawaban yang diberikan. Miskonsepsi yang dialami siswa sebagain besar terjadi pada soal menyelesaiakan permasalahan sehari-hari yang berkaitan dengan sistem persamaan linear dua variabel yaitu sisiwa kurang mampu menerjemahkan soal cerita ke bentuk matematika, sehingga tidak mampu menyelesaikan permasalahan yang berkaitan dengan sistem persamaan linear dua variabel. Serta pada soal menentukan himpunan penyelesaian sistem persamaan linear dua variabel. Adapun jumlah 
siswa yang mengalami miskonsepsi sebanyak 5 siswa yaitu MZA, ENML,WH dan ERS. Subjek MVR mengalami miskonsepsi karena menganggap beda variabel yang sama yang dipisahkan dengan tanda sama dengan seperti pada soal . Subjek ENML dan subjek WH mengalami miskonsepsi karena belum bisa membedakan pengertian koefisien dan variabel. Subjek ERS mengalami miskonsepsi yaitu belum bisa menentukan sebarang bilangan pada operasi penyelesaian menggunakan metode eliminasi. Adapun subjek MZA mengalami miskonsepsi yaitu belum memahami unsur mana yang dimisalkan dengan variabel.

Menebak yaitu siswa yang mampu memilih jawaban yang benar, namun tidak mampu memberikan alasan yang benar serta tidak yakin dengan jawaban yang diberikan. Selain itu, siswa yang menebak adalah siswa yang memilih jawaban yang salah, memberikan alasan yang benar serta tidak meyakini jawaban yang diberikan. Adapun jumlah siswa yang mengalami menebak sebanyak 3 siswa yaitu, NH, ENML, ERS.Lucky guess yaitu siswa yang mampu memilih jawaban yang benar, memberikan jawaban yang benar, namun tidak yakin dengan jawaban yang diberikan. Adapun jumlah siswa yang mengalami lucky guess sebanyak 5 siswa yaitu, MVR, ENML, WH, ERS, dan MZA. Lack Of Knowlegde (kurang pengetahuan) yaitu siswa yang memilih jawaban yang salah, memberikan alasan yang salah serta tidak yakin dengan jawaban yang diberikan. Namun, pada penelitian ini tidak ada siswa yang mengalami Lack Of Knowlegde. Disarankan bagi peneliti selanjutnya, agar melakukan penelitian lanjutan dalam mengidentifikasi miskonsepsi yang dialami siswa bukan hanya pada materi sisitem persamaan linear dua variabel tetapi materi lain yang cenderung mengalami miskonsepsi.

\section{DAFTAR PUSTAKA}

Depdiknas.2003. Undang-Undang Repoblik Indonesia Nomor 20 Tahun 2003 Tentang Sistem Pendidikan Nasional.Jakarta : Depdiknas.

Farida, Anisatul.2016. Analisis Miskonsepsi Siswa Terhadap Simbol Dan Istilah Matematika Pada Konsep Hubungan Bangun Datar Segiempat Melalui Permainan Dengan Alat Praga Di SD Muhammadiyah 1 Surakarta. Konferensi Nasional penelitian matematika dan Pembelajarannya (KNPMP I). (online). Universitas Muhammadiyah Surakarta.

Kemendikbud.Laporan Hasil Ujian Nasional.(Online). (https://hasilun.puspendik.kemdi kbud.go.id/\#2019!smp!capaian_nasional!199\&99\&999!T\&T\&T\&T\&I\&!I!\&).

Diakses 30 September 2019.

Maulini, S., Kurniawan, Y., \& Muliyani, R. (2017). The Three Tier-Test Untuk Mengungkap Kuantitas Siswa Yang Miskonsepsi Pada Konsep Konstanta Pegas. JIPF (Jurnal Ilmu Pendidikan Fisika), 2(2), 28.

Marsitin, R. (2018). Koneksi Matematis dan Berpikir Kreatif dalam Pembelajaran Matematika dengan Teori APOS. Al-Khwarizmi: Jurnal Pendidikan Matematika Dan Ilmu Pengetahuan Alam, 5(1), 87-100. https://doi.org/10.24256/jpmipa.v5i1.268

Murniasih, T. R., Ferdiani, R. D., Agustina, R., \& Kanjuruhan, U. (2018). IDENTIFIKASI MISKONSEPSI SISWA SMP PADA MATERI LINGKARAN DENGAN MENGGUNAKAN THREE TIER-TEST. 9(September), 174-180.

Savitri, M. E., Mardiyana, \& Subanti, S. (2016). Analisis Miskonsepsi Siswa Pada Materi Pecahan Dalam Bentuk Aljabar Ditinjau Dari Gaya Kognitif Siswa Kelas Viii Di Smp Negeri 2 Adimulyo Kabupaten Kebumen Tahun Ajaran 2013/2014. Jurnal Elektronik Pembelajaran Matematika, 4(4), 401-413.

Siagian, M. D. (2016). Kemampuan Koneksi Matematik Dalam Pembelajaran Matematika. MES (Journal of Mathematics Education and Science), 2(1), 58-67.

Tridiyanti, E. P., \& Yuliani. (2017). BioEdu PROFIL OF MISCONCEPTION BY USING THREE TIER TEST ON CARBOHYDRATE BioEdu. 6(3), 297-303.

Zulfa, Indana. (2013). " Analisis 'Kesalahan Siswa Kelas II MTs Alkhoiriyah dalam Menyelesaikan Soal Cerita yang Terkait dengan Sistem Persamaan Linear Dua Peubah ” Tesis Pendidikan Matematika, (Surabaya: Perpustakan Pasca Sarjana Unesa, 2011), hal. 29. 7-18. 